われわれの症例では，心不全の急激な進行に伴い内科 的治療の限界之判断した症例が 2 例みられ，緊急手術を 行った。しかし, それらの症例でも術直前の血液培養や 切除弁の培養では細菌は検出されなかった。

細菌性心内膜炎の手術方針としては，荒廃弁の切除， 感染巣の処置, および先天性心疾患を伴う場合にはをの 処置屯同時に行い，血行動態の正常化を図るととにあ る. 慢性期の手術では完全な血行動態の正常化を期する ことが望ましいと考えられる.

しかし，緊急手術となる場合には，左心系の弁置換 と, 先天性心疾患を合併すればその根治術を行い, 右心 系の罹患弁は切除，または切除後形成術を施行するのみ に止めて沶いてひ，肺高血圧がなければ急性期を乗り越 えることが可能であるとされており して手術侵襲の軽減之，手術時間の短縮を図るほうが得 策と考えられる.われわれの経験した緊急手術 2 症例で あ同様であり，右心系への手術は最小限に止めたが，術 後急性期を乗り切ることができ, 右心系の弁置換の必要
は認めていない。

結語

1）感染性内膜炎の治療は，外科的治療を念頭におき ながら，強力な抗生物質，強心利尿剂投与等内科的治療 を施行し，必要ならば時期を失せず外科治療を行うこと が必要である.

2）心内シャントを有する 2 症例では，内科的治療に 抵抗し両心不全の進行, 他臟器の不全のために緊急手術 を要し，また，他の症例に比べ $D_{\mathrm{d}}$ の改善は遅れる傾 向にあった。

3）いずれの症例屯感染の再発はなく，経過観察中で ある。

文 献 1) Nelson, R. J. et al.: J. Thorac. Cardiovasc. Surg. 87: 493, $1984 . \quad$ 2) Dismukes, E. W.: Cardiovasc. Clin. 11 : 189, 1981. 3) Mills, S. A.: Ann. Surg. 195: 367, 1982. 4) DiNubile, M. J.: Ann. Intern. Med. 96: 650, 1982.

\title{
272 感染性心内膜炎に対する外科治療経験
}

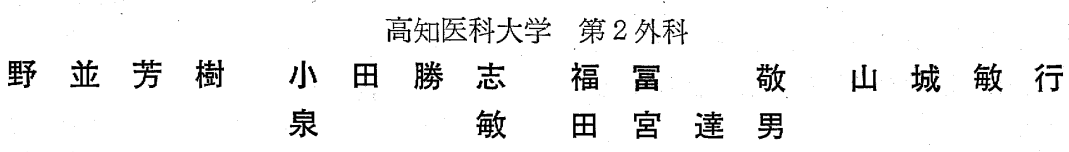

感染性心膜炎（以下 IE）に対する手術治療は内科療 法による炎症治癒期に行うことが望ましいが，心不全症 状が急速に進行する場合には活動期といえども早期手術 が必要となる.今回, 教室での IE 症例を検討したので 反省点を含め報告する.

\section{対象}

1983 年 10 月より 1989 年 9 月までの 6 年間に当科で 外科治療莡行った IE 症例は 14 例（自然弁感染 NVE 11 例, 先天性心疾患隹合併したもの CHD + IE 2 例, 置換機械弁感染 PVE 早期 1 例) で年齢は 21 歳から 78 歳および平均 49 歳, 男 11 例女 3 例であった（表 1 ). これは同期間の全弁置換術症例 97 例の $12 \%$ に相当す る.

\section{治療および結果}

感染部位は NVE : 大動脈弁 5 例, 僧帽弁 5 例, 大動 脈弁＋僧帽弁 1 例， CHD + IE 三尖弁，肺動脈弁下部 おのおの 1 例, PVE: 大動脈 SJM 弁1例で, 手術は AVR 6 例, MVR 5 例, AVR+MVR 1 例, VSD closure 2 例（含 VSD re-closure 1 例）を行った. 本症手 術では感染病巣の郭清除去に留意し, 置換弁は妊娠の可

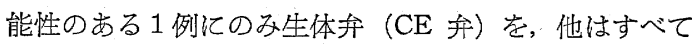
機械弁（BS 弁 9 例, SJM 弁 3 例) を用いた。なお， AVR 症例では全例仁大動脈中膜を通し并輸と人工弁固 定をより強固なものとした．さらに弁輪部膿瘍廓清のた め 2 例に大動脈壁外通針固定を追加し同部を補強した.

IE 発症から手術までの期間は 2 週間から 6 か月に及 び平均 1 か月で全例，抗生剤の投与を必要とした，なか 
表 1 感染性心内膜炎手術症例

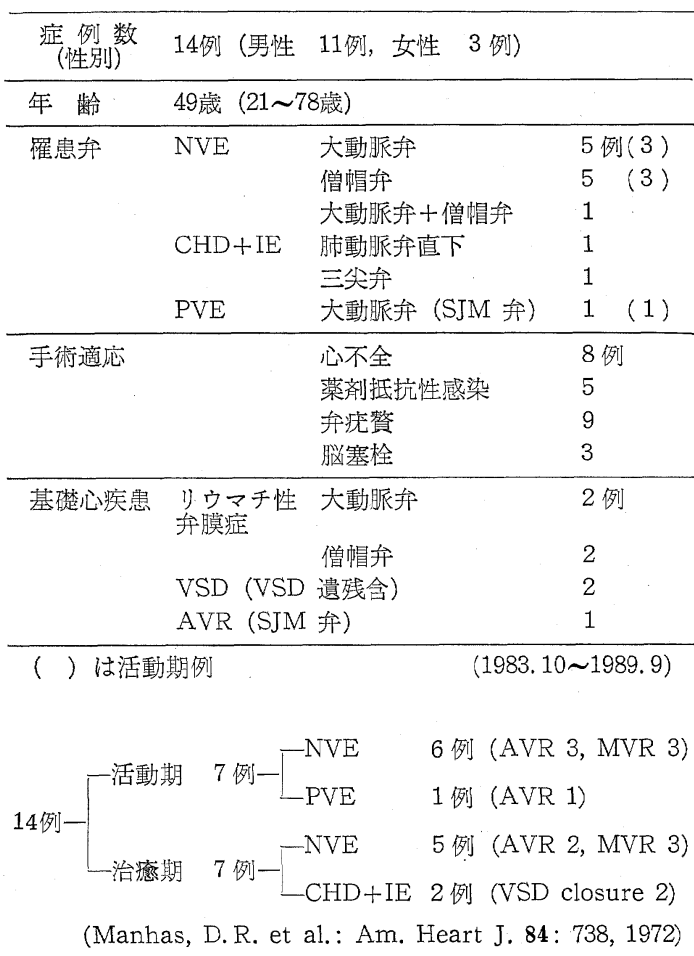

です Manhas らに従って活動期とした 7 症例のうち僧 帽弁置換後, 切除弁に黄色ブドゥ球菌を認め初めて IE と判定した 1 例を除く 6 例 (NVE 5 例 PVE 早期 1 例) では，5例に NYHA III 以上の心不全状態を，4例飞
疮贅遊離の危険があり, 術前 4 日から 36 日（平均 17 日）間の抗生剂投与の後, 白血球増多, CRP 陽性が残 存した炎症活動期代手術を行わざるをえなかった。さら に重篤で緊急手術要請となった症例は 2 例であったが 1 例は繁急手術直前に急死した。

術後，治癒期症例 7 例（NVE 5 例，CHD + IE 2 例） では 2 週間あまりで全例炎症反応が陰性化し，とくに合 併症なく湏調汇軽快退院した。

これに対して，活動期症例の 6 例では，炎症反応が 10 日から 8 週間あまり (平均 $3 ， 6$ 週) 持続し, 合併症と して中等度肝機能障害を 2 例に縦隔炎, 胃塞栓による胃 出血をおのおの 1 例に認めた（表 2 ).

起炎菌の固定は，血液あるいは組織培養により9 例 (緑連菌 3 例, ブドウ球菌 2 例, 連鎖球菌 2 例, グラム 陽性球菌 2 例) に可能であった。 なかであ緑連菌 2 例, 連鎖球菌 1 例, 表皮ブドウ球菌 1 例その他 5 例計 9 例で は弁，弁㫻部に疮贅を認め，脳塞栓を 2 例に発症してい た (表 3 ).

緊急手術要請となった 2 症例は 56 歳男性 : 突然の 39 度の発熱加ら AR をきたし PCG 2000 万単位, SM 2 $\mathrm{g}, \mathrm{CMZ} 4 \mathrm{~g}$ の連日投与を 2 週間あまり行ったとてろ, 心不全, 脱水および抗生剂の副作用から C cr $18 \mathrm{ml} / \mathrm{ml}$ と腎不全症状が急速に進行したため術前人工透析を数回 行った後 AVR 施行し, Ccr $55 \mathrm{ml} / \mathrm{ml}$ 之腎機能の回復 を得た。

69 歳男性: 初回 BS 弁で AVR 後, 十二指腸潰湯の ため抗凝固剤の服用を一時中止せざるをえなかった症例

表 2 活動期手術症例

\begin{tabular}{|c|c|c|c|c|c|c|c|c|c|c|}
\hline No & 症例 & $\begin{array}{c}\text { 性 年齢 } \\
\text { (歳) }\end{array}$ & 起 炎 菌 & 術前抗生剂 & $\begin{array}{l}\text { 投与 } \\
\text { 期間 } \\
(\text { (日) }\end{array}$ & 手術適応 & 術 式 & $\begin{array}{l}\text { 術後炎 } \\
\text { 症消退 } \\
\text { 期間 }\end{array}$ & 合 储症 & 転 帰 \\
\hline 1 & & M 65 & unknown & PCG 1600 万U & 24 & Vegetation & $\begin{array}{c}\text { MVR } \\
(\mathrm{BS})\end{array}$ & $10 \mathrm{D}$ & $\begin{array}{l}\text { LA thrombectomy } \\
\text { mediastinitis }\end{array}$ & alive \\
\hline 2 & & $\mathrm{M} \quad 48$ & $\begin{array}{l}\text { Streptococcus } \\
\text { viridans }\end{array}$ & $\begin{array}{l}\text { PCG } 1600 \text { 万U } \\
\text { SM } 1 \mathrm{~g}\end{array}$ & 18 & $\begin{array}{l}\mathrm{CHF} \\
\text { Vegetation }\end{array}$ & $\begin{array}{l}\text { MVR } \\
\text { (SJM) }\end{array}$ & $4 \mathrm{~W}$ & Liver dysfunction & alive \\
\hline 3 & & M 67 & $\begin{array}{l}\text { Staphylococcus } \\
\text { aureus }\end{array}$ & $(-)$ & $(-)$ & Vegetation & $\begin{array}{c}\text { MVR } \\
\text { (BS) }\end{array}$ & $2 \mathrm{~W}$ & $\begin{array}{l}\text { Gastric bleeding } \\
\text { Partial gastrectomy }\end{array}$ & alive \\
\hline 4 & & M 51 & $\alpha$-Streptococcus & $\begin{array}{l}\text { PCG } 2000 \text { 万U } \\
\text { SM } 1 \mathrm{~g}\end{array}$ & 8 & $\begin{array}{l}\mathrm{CHF} \\
\text { Vegetation } \\
\text { Resist. infect. }\end{array}$ & $\begin{array}{l}\text { AVR } \\
(\mathrm{SJM})\end{array}$ & $4 \mathrm{~W}$ & $(-)$ & alive \\
\hline 5 & & M 56 & unknown & $\begin{array}{l}\text { PCG } 2000 \text { 万U } \\
\text { SM } 2 \mathrm{~g} \\
\text { CMZ } 4 \mathrm{~g}\end{array}$ & 36 & $\begin{array}{l}\mathrm{CHF} \\
\text { Renal failure }\end{array}$ & $\begin{array}{l}\text { AVR } \\
(\mathrm{BS})\end{array}$ & $3 \mathrm{~W}$ & Pre-op HD & alive \\
\hline 6 & & 78 & $\begin{array}{l}\text { Streptococcus } \\
\text { pneumoniae }\end{array}$ & PCG 1200 万U & 12 & $\mathrm{CHF}$ & $\begin{array}{c}\mathrm{AVR} \\
(\mathrm{BS})\end{array}$ & $3 \mathrm{~W}$ & $(-)$ & alive \\
\hline $7^{*}$ & & M 70 & $\begin{array}{l}\text { Staphylococcus } \\
\text { epidermidis }\end{array}$ & PCG 2000 万U & 4 & $\begin{array}{l}\text { CHF } \\
\text { Resist. infect. }\end{array}$ & $\begin{array}{c}\text { re-AVR } \\
\text { (BS) }\end{array}$ & $2 \mathrm{M}$ & Liver dysfunction & alive \\
\hline
\end{tabular}

*: PVE 症例 
表 3 Vegetation の有無による比較（術前）

\begin{tabular}{lll}
\hline & $\begin{array}{c}\mathrm{V}(+) \\
(n=9)\end{array}$ & $\begin{array}{l}\mathrm{V}(-) \\
(n=5)\end{array}$ \\
\hline 感染部位 & $5(56 \%)$ & $1(20 \%)$ \\
$\quad$ 僧帽弁 & $3(33 \%)$ & $3(60 \%)$ \\
大動脈弁 & $1(11 \%)$ & 0 \\
$\quad$ 人工弁 & 0 & $2(40 \%)$ \\
$\quad$ 心室中隔欠損 & & \\
起炎菌 & 2 & 1 \\
$\quad$ Streptococcus viridans & 1 & 0 \\
$\alpha$-Streptococcus & 0 & 1 \\
Streptococcus pneumoniae & 0 & 2 \\
Staphylococcus aureus & 1 & 0 \\
$\quad$ Staphylococcus epidermidis & 1 & 1 \\
$\quad$ 同定不能菌 & 1 & 0 \\
培養陰性 & 4 & \\
合併症 & & 1 \\
$\quad$ 脳塞栓 & $2(22 \%)$ & 1 \\
$\quad$ 眼底 Roth's spots & $1(11 \%)$ & 0 \\
外科治療 & & \\
$\quad$ 活動期 & $5(57 \%)$ & $2(40 \%)$ \\
治癒期 & $4(33 \%)$ & $3(60 \%)$ \\
\hline
\end{tabular}

で反復するブブドウ球菌感染の PVE をきたしたが，抗 生剂で寛解を得ていたため, 再手術を拒否していたが, 3 年後, 発熱, 倦点感が生じ再々入院した. やはりての 時点でも再手術を拒否したが急速に心不全症状の憎悪を きたし，緊急手術直前に死亡した。次に MVR 後, 胃 塞栓のため胃潰瘍からの大量出血のため緊急胃切術施行 した症例を呈示する。

67 歳男性 : 真性多血小板血症を合併していた. 当科 入院 1 か月前に脳塞栓症を起てしていた。僧帽弁は前尖 に亀裂様の潰癔を形成しており, 弁は炎症所見に富み, 弁培養で黄色ブドウ球菌を認めた．MVR おょび胃切 後, 炎症反応は比較的早期に軽快したが, 心房細動, 多 血小板血症を合併し, 胃切除断端からの出血が持続し たため heparin 等の抗凝固療法ができず GabexateMesilate (FOY-R) の長期投与行ったところ, 血栓の形 成もなく順調に回収し退院した。

\section{考案}

IE の活動期症例に対しては抗生剂でできるかぎり炎
症反応を抑えるととが原則であるが，心不全症状，病贅 形成例では活動期といえども外科手術対象となる ${ }^{11}$. Manhas ら 2) の定義に従って自験例を分類すると7 例が 活動期に相当した. 手術例では 2 例に并輪周囲膿韵が存 在しており, 大動脈壁外通針固定術式を用いた. 他は通 常の弁置換術を行ったが，その成績は良好であった．自 験例ではなかったがさらに炎症が弁輪部を越えて広く波 及しているときには大動脈弁位では translocation"1》 行うことああるが僧帽弁位では種々の術式が要求され る. 組織破壊は最む浪贅が多く9例汇認め, うち緑連菌 感染を 2 例に認めた。

また, 弁選択関しては, Magilligan 弓3! は IE 症 例に皘極的に生体弁を用いているが生体弁が感染に弱い との意見ああり, 自験例では妊娠の可能性のある症例に のみ用い，他は機械弁を用いた結果，現在に至るまで良 好な経過を得た.PVE では疮贅の診断は困難であり, また晚期例では抗生前で寛解を得やすいため，その長期 の治療過程のうちに心筋の脆弱化をきたしやすくいった ん, 心不全が発現すると急激なととああり，その管理に おいてはより厳密な経過観察が重要であり, 遷延化傾向 にあれば時期を逸することなく積極的に手術を行うべき あのと改めて痛感した。

\section{結語}

1) IE の 14 例に弁置換術を行ったが，抗生剂の投 与下の手術成績は炎症活動残存にかかわらず, きわめて 良好（急性腎不全症例であ人工透析を行い，緊急 AVR を施行することにより腎機能の改善を得た. 術後, 胃切 を要した症例では抗凝固療法として Gabexate Mesilate を用い血栓形成むなく順調な回復を示した）であった。

2) 晚期 PVE 症例では患者の自覚症状がそしく化学 潦法で寛解を繰り返したため手術の時期を逸し，重篤な 心筋障害をきたした。 心機能低下傾向例, 疮贅形成例で はより，積極的に手術を行うべきであると思われた。

文 献 1) 小柳 仁ほか：感染・炎症・免疫 13: 203,1983. 2) Manhas, D. R. et al.: Am. Heart J. 84: 738, 1972. 3) Magilligan, D. J., Jr. et al.: Ann. Thorac. 203, 1983. 